\title{
PSYCHROPHILIC ENDOPHYTIC Pseudomonas AS POTENTIAL AGENTS IN BIOCONTROL OF PHYTOPATHOGENIC AND PUTREFACTIVE MICROORGANISMS DURING POTATO STORAGE
}

\section{A.V. SHCHERBAKOV ${ }^{1}$, E.N. SHCHERBAKOVA ${ }^{1}$, S.A. MULINA ${ }^{1,2}$, P.Yu. ROTS', 2 , R.F. DARYU ${ }^{3}$, E.I. KIPRUSHKINA ${ }^{4}$, L.N. GONCHAR ${ }^{5}$, V.K. CHEBOTAR'1}

1All-Russian Research Institute for Agricultural Microbiology, Federal Agency of Scientific Organizations, 3, sh. Podbel'skogo, St. Petersburg, 196608 Russia, e-mail microbe-club@inbox.ru, alonagonchar@mail.ru, mulina_sa@mail.ru, vladchebotar@rambler.ru;

${ }^{2}$ Saint Petersburg State Technical University, 26, Moskovskii prosp., St. Petersburg, 190013 Russia;

${ }^{3}$ Sup'Biotech private engineering school, 66 rue Guy Môquet, Villejuif, Paris, 94800 France;

${ }^{4}$ ITMO University (Saint Petersburg National Research University of Information Technologies, Mechanics and Optics), 9, ul. Lomonosova, St. Petersburg, 191002 Russia;

$5_{\text {National University of Nature and Bioresources of Ukraine, 15, vul. Geroiv Oborony, m. Kiev, } 03041 \mathrm{Ukraine}}$ ORCID:

Shcherbakov A.V. orcid.org/0000-0001-6638-8595

Shcherbakova E.N. orcid.org/0000-0002-7871-034X

Mulina S.A. orcid.org/0000-0001-6554-4111

Rots P.Yu. orcid.org/0000-0003-0638-7587

The authors declare no conflict of interests

Acknowledgements:

Experiments were performed using equipment of the Center of Genome Technologies and Cell Biology (ARRIAM) Supported by Russian Science Foundation (grant № 14-16-00146)

Received December 11, 2016
Daryu R.F. orcid.org/0000-0003-2516-9200

Kiprushkina E.I. orcid.org/0000-0001-5350-4550

Gonchar L.N. orcid.org/0000-0002-3628-6659

Chebotar' V.K. orcid.org/0000-0001-9762-989X

\begin{abstract}
Abundant pathogens which attack seed and food potato tubers are a serious problem of the modern potato growing that causes significant losses during storage. Regular use of chemical fungicides and agrochemicals has led to emergence of resistance and an increased aggressiveness of plant pathogenic microorganisms. New fungal and bacterial strains and races are also appearing which spread rapidly and cause great damage to agricultural production. In this regard, the biologicals based on biocontrol microorganisms, instead of chemicals, are considered particularly relevant to protect seed and food potatoes from infectious diseases. A genus Pseudomonas belonging to the group of plant-growth promoting rhizobacteria (PGPR) includes species most effectively colonizing higher plants and used as active agents of biological products. Scientific novelty of our work lies in the fact that this study is the first to report the effect of psychrophilic strain Pseudomonas spp. RF13H on the storage of potato tubers. The cold resistant commercial varieties recommended for cultivation in the Leningrad region has been involved. For the first time we estimated the efficiency of tubers protection from a number of pathogenic microorganisms under refrigerated storage, assessed the population dynamics of introduced strain, and visualized the pattern of bacteria distribution and localization on the surface, using fluorescent in situ hybridization and confocal laser scanning microscopy. Using molecular genetic analysis, we have clarified the taxonomic position of several Pseudomonas strains, including psychrophilic strain Pseudomonas spp. RF13H. This strain possessed fungicidal and bactericidal activity against saprogenic and pathogenic microorganisms and was agronomically and physiologically tested. Its growth at low temperatures and production of auxin-like phytohormones were studied. Pseudomonas spp. RF13H influenced positively preservation and biochemical processes in potato tubers under refrigerated storage. Its microcolonies were often localized in different cracks, grooves and recesses on the stored tuber surface that indicated beneficial plant-microbial relations and explained a strategy for tuber colonization at room and low temperature during storage. The occurrence of surface phytopathogenic microorganisms decreased in the presence of Pseudomonas spp. RF13H, and the average number of all type-infected tubers was about $50 \%$ lower among those treated with Pseudomonas spp. RF13H comparing to untreated ones. This trend continued for 3 month storage, i.e. the amount of infected untreated tubers reached $30 \%$ and reduced up to 10-13\%, when treatment with biocontrol strain. At a temperature of $4{ }^{\circ} \mathrm{C}$, the bacterial counts was quite stable for 5 months, and then significantly decreased (up to trace quantities) to the end of storage. The bacteria concentrated at the boundaries between the individual cells of tuber periderm and in the places of exudation of biochemical substances that serves as nutrients for bacteria. Introduc-
\end{abstract}


tion of Pseudomonas spp. RF13H was shown to contribute to redox processes (activation of antioxidant protection system enzymes - catalase, peroxidase, superoxide dismutase) thus increasing plant resistance to pathogens. Additionally, this strain has a positive effect on the microbiome composition in potato epidermis. Induction of own immunity and creation of a barrier preventing pathogen penetration helped to reduce infection in the potatoes tuber. bridization

Keywords: Pseudomonas, potato, biocontrol of plant pathogens, fluorescence in situ hy-

Rapid increase in plant pathogen resistance and emergence of new species, including those from imported seeds, has been observed in recent years [1, $2]$. Both losses during storage and a threat of re-infection of vegetating plants are related to tuber infection in potato farming. According to FAO, per capita consumption of potato in Russia is one of the world's largest, i.e. $130 \mathrm{~kg}$ annually [3]. Potato is a crop with high potential yield, but it is extremely sensitive to fungal, bacterial and viral pathogens due to mostly vegetative reproduction.

Increase in resistance of pathogens and disease outbreaks lead to use of increased doses of chemicals, which, in its turn, induces a new increase in resistance of pathogens. Thus, biologicals based on biocontrol microorganisms, i.e. natural ecosystem inhabitants [4] which provide selective action and allow to avoid adverse effects on biocenoses and yield [5], are relevant for environmental stability and protection in plant growing. The majority of such microorganisms synthesize various metabolites initiating a cascade of defense reactions in a plant [6]. Apart from that, during interaction with a plant bacteria can increase its viability, thus regulating the number of plant pathogens. As a result, several protection levels are formed, including direct competition with a plant pathogen, production of biofilms and antibiotic substances, and induction of plant immunity.

Endophytic bacteria [7, 8] inhabiting plant tissues, which makes them less dependent on external factors, are of particular interest. Upon introduction into plant tissues endophytes with a complex of agriculturally valuable traits may contribute to formation of durable macroorganism protection from stresses [9].

The study of microbiome in potato (Solanum tuberosum L.) included both rhizosphere and endosphere [10-12]. It has been shown that biodiversity of microorganisms often depends on a variety and plant development phase. Such studies were mostly performed in vegetating parts [13-15], rather than tubers upon harvesting. In one of the studies the authors evaluated bacterial population dynamics in tubers during storage for several taxa [16]. The report on analysis of tuber endophytic microbiome during storage with the use of both conventional methods of microorganism isolation and identification and high-throughput next generation sequencing (NGS) shall be noted among recent publications of particular interest [17]. It should be noted that bacteria isolation from tissue upon surface sterilization is not enough to assign them to endophytes. Bacteria visualization inside a plant is required, e.g. using fluorescent markers (probes or proteins) $[18,19]$.

Currently, global practice of bacterial product application for potato storage has just started developing, that is why many questions arise on mechanisms of interaction in a complex system plant-pathogen-antagonist. Particularly, what happens to the strain upon introduction and during tubers storage, how its count and distribution on tuber surface change, and how storage temperature affects these processes. Finding answers to these questions will allow forecasting effects and adjusting bacterials application. Involvement of local varieties in such experiments is helpful in development of a comprehensive practical model.

Scientific novelty of this work is examination of effect of Pseudomonas sp. RF13H psychrophilic bacterial strain on tuber preservation in cold-resistant potato varieties recommended for growing in Leningrad region (Nevskii and Su- 
darynya), performed for the first time. Effectiveness of tuber protection from several plant pathogens during refrigerated storage has been determined, introduced strain count dynamics on tuber surface during the whole storage period has been evaluated. Colonization of tuber surface with Pseudomonas sp. RF13H, the nature of which suggests mutually beneficial plant-microbial relations, has been studied for the first time using modern visualization methods. The results obtained using commercial varieties, make it possible to develop practical recommendations on use of Pseudomonas sp. RF13H psychrophilic strain in potato production, storage and reproduction.

This work is focused on clarification of Pseudomonas sp. RF13H psychrophilic strain taxonomic position and examination of its biocontrol effectiveness (preservation of potato tubers and biochemical processes therein), as well as localization of bacteria on tuber surface under refrigerated storage.

Techniques. Potato (Solanum tuberosum L.) varieties Nevskii (middlelate) and Sudarynya (middle-early) were the objects of strain biocontrol effect study. Commercial potato batches were obtained from Belogorka Leningrad Agricultural Research Institute.

Pseudomonad strains, including Pseudomonas sp. RF13H, were isolated from Sphagnum fallax sphagnum moss tissues as a members of extremophilic endophytic community [20]. The culture was grown for 48 hours at $28{ }^{\circ} \mathrm{C}$ in TSB liquid medium (Tryptic Soy Broth, Scharlab, S.L., Spain), and used to prepared working suspension of $10^{8} \mathrm{CFU} / \mathrm{ml}$. Potato tubers were sprayed with a bacterial suspension (water in control), dried in air and placed for storage at room temperature and at $4{ }^{\circ} \mathrm{C}$. Test cultures used were the main Solanaceae family pathogens, inducing causative agents of vegetative organ diseases in plants during refrigerated storage (Fusarium solani, Alternaria alternata, Pseudomonas solanacearum, Clavibacter michiganensis subsp. sepedonicus). Micromycetes were grown on potato dextrose agar (PDA) (BD, USA), phytopathogenic bacteria on starvation potato agar medium (All-Russia Research Institute of Agricultural Microbiology - ARRIAM). Strains of phytopathogenic fungi and bacteria were obtained from the collection of Laboratory of microbial preparation technology (ARRIAM).

Standard method of DNA extraction from pure 24-hour cultures of studied bacterial strains (cell lysis using lysozyme, proteinase K and SDS and extraction with phenol:chloroform) was used for analysis of 16S rRNA gene regions V3-V6 variability. PCR was performed in a Bio-Rad C1000 thermal cycler (BioRad, USA). DNA of 16S rRNA gene was amplified using BD1/FD1 primers in the respective mode [21]. Upon gel purification, the fragments were sequenced with internal primers $\mathrm{fD} 1 / \mathrm{rD} 1$ to variable regions V3-V6 of $16 \mathrm{~S}$ rRNA gene according to the protocol of Beckman Coulter, Inc. (USA) for an 8-channel sequencer SEQ8000 using commercial kit SEQ Dye Terminator Cycle Sequencing (DTCS) with Quick Start Kit (Beckman Coulter, Inc., USA).

Identification of isolate species was performed using BLAST (GenBank, http://www.ncbi.nlm.nih.gov/blast/) and Ribosomal Database Project (http://rdp.cme.msu.edu/) software. Alignment of identified nucleotide sequences with reference sequences from GenBank and phylogenetic tree construction was performed using UGENE (UniPro, Russia).

During examination of physiological properties of strains their fungicidal and bactericidal activity, growth rate at low temperatures $\left(4-10{ }^{\circ} \mathrm{C}\right.$ ) and production of auxin-like phytohormones were compared. Well method [22] was applied for fungicidal activity assessment, agar blocks [23] for bactericidal activity assessment. The number of introduced and autochthon microorganisms on tuber surface was estimated using microbiological culture [24, 25]. Auxin content 
in culture broth extracts was analyzed by a high performance liquid chromatography (HPLC) system Waters ACQUITY UPLC H-class with fluorescence detector (Waters, USA).

Antioxidant protection system activity in tubers was assayed by malondialdehyde (MDA) and peroxydase (PO) content in seedlings. Lipid peroxidation (LPO) was evaluated by the concentration of colored complex formed by MDA in acidic medium at a temperature of about $100{ }^{\circ} \mathrm{C}$ [26], catalase activity (CAT) was estimated by hydrogen peroxide degradation rate, PO activity - as optical density of guaiacol oxidation products [27]. For superoxide dismutase (SOD) activity unit, $50 \%$ inhibition of formazan formation in a reaction with nitroblue tetrazolium was taken [28].

Oligonucleotide target probe for fluorescence in situ hybridization (FISH) was designed using IDT Internet resource [28]. The developed probe was marked with 6FAM fluorochrome. Probe hybridization was performed at $60{ }^{\circ} \mathrm{C}$ for $90 \mathrm{~min}$. Preparation of plant tissues and hybridization were performed as described $[29,30]$. The samples were analyzed using Leica TCS SPE confocal microscope (Leica Mikrosysteme Vertrieb GmbH, Germany). Laser $(\lambda=488 \mathrm{~nm}$ ) was used for oligonucleotide probe fluorescence detection, fluorescence was registered within the range of 508-566 $\mathrm{nm}$. Images were visualized using Leica Confocal Software (Leica Mikrosysteme Vertrieb GmbH, Germany).

Each index (fungicidal and bactericidal activity, colony growth rate at low temperatures, enzyme activity and microorganism counts on tuber surface) was evaluated in three independent experiments. Auxin content analysis was performed in triplicate. Statistical processing of numerical values was performed using DIANA software (ARRIAM) at significance level $\mathrm{p}=0.05$.

Results. Taxonomy of studied isolates. Pseudomonas genus is extremely diverse, and its taxonomy is still being clarified [31, 32]. Base on the obtained morphological, physiological and biochemical characteristics, 10 studied strains from the laboratory collection were assigned to the group P. fluorescens $-P$. asplenii- $P$. poae.

Analysis of variable regions V3-V6 of 16S-rRNA gene was performed to obtain more detailed information on taxonomic position of studied strains. The greatest variability was observed for the regions at positions 557-586 and 624-685, corresponding to nucleotide positions in 16S rRNA gene of Escherichia coli (Fig. 1, A). Obtained sequences were aligned with available reference sequences from GenBank. Consensus alignments for each proposed specie ( $P$. fluorescens, P. poae, $P$. asplenii, $P$. koreensis, $P$. moraviensis) were used as references. Phylogenetic tree (see Fig. 1, B) constructed based on the said regions reflected taxonomic position of studied isolates as follows: AF12F, RM13D, AF24C strains were more closely related to $P$. koreensis and $P$. moraviensis subgroup, while RM11C, RM14B were more closely related to P. asplenii. RF14J, RF12C, RF14H, RM13C, and RF13H strains shall be possibly considered as representatives of species which have not been described yet.

Ability of psychrophilic growth and development at $0-10{ }^{\circ} \mathrm{C}$, inhibition of phytopathogenic and putrefactive microorganisms, production of auxin-like phytohormones (indolyl-3-acetic, indolyl-3-carboxylic and indolyl-3-lactic acids) was examined in all strains. As it has been shown, pseudomonade strains differed by growth rate at low temperatures which decreased significantly in the majority of the strains at $6-7{ }^{\circ} \mathrm{C}$ and was completely inhibited at $5{ }^{\circ} \mathrm{C}$. However, at $7-10{ }^{\circ} \mathrm{C}$ all strains formed colonies 3-4 mm in diameter within 7 day growing on $\mathrm{R}_{2} \mathrm{~A}$ agar. $\mathrm{RF} 13 \mathrm{H}$ and RM14B strain growth was observed at positive temperatures $\left(2-4{ }^{\circ} \mathrm{C}\right)$ close to $0^{\circ} \mathrm{C}$ : in 7 days of low-temperature growth the bacteria formed colonies 1- 

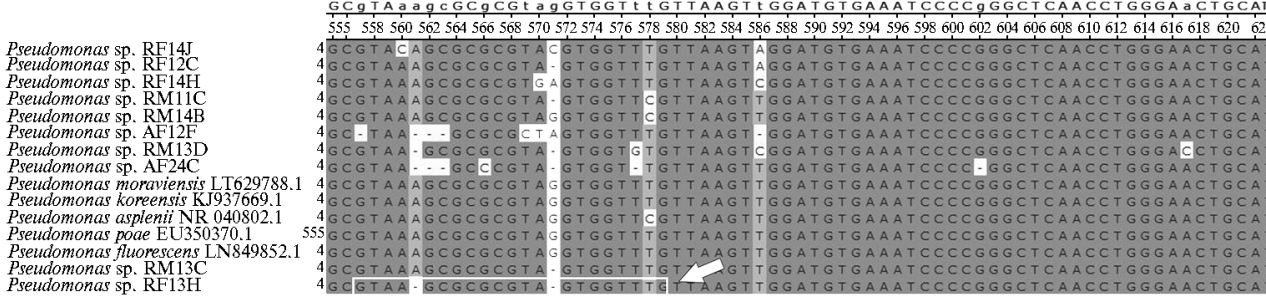

Pseudomonas sp. RF14J Pseudomonas sp. RF14H Pseudomonas sp. RM11C Pseudomonas sp. RM14R Pseudomonas sp. AF12F Pseudomonas sp. RM13D
Pseudomonas sp. AF 24C Pseudomonas moraviensis LT629788.1 Pseldomonas koreensis KJ937669.1 Pseudomonas asplenii NR 040802.1 Pseudomonas poae EU 350370.1 Pseudomonas fluorescens LN849852.1 Pseldomonas sp. RM13C

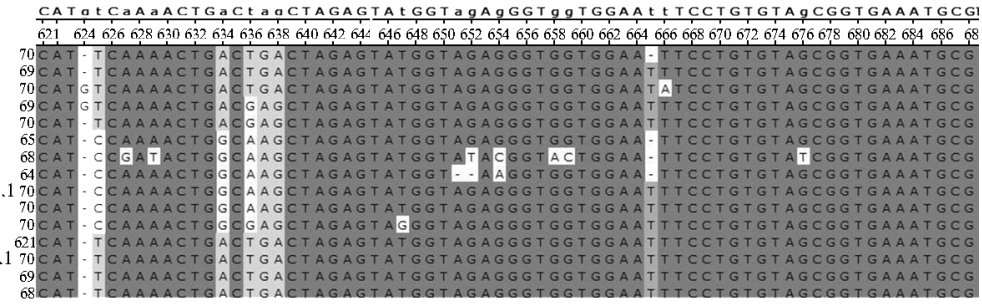

B

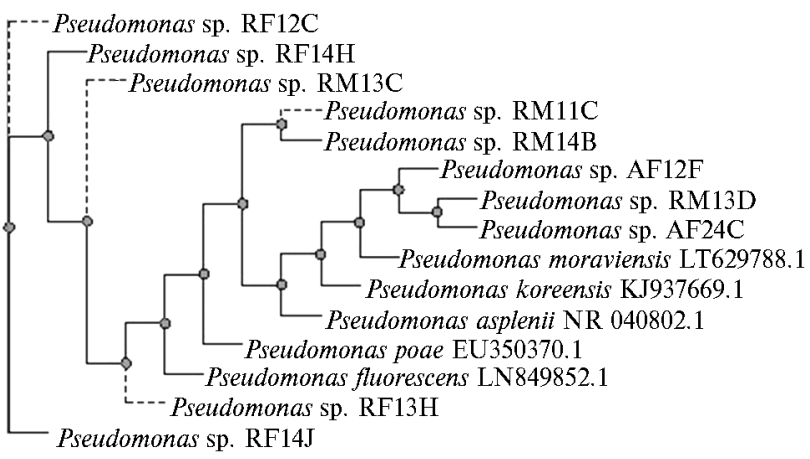

Fig. 1. Regions of variable fragments V3-V6 of 16S rRNA gene of studied pseudomonades with replacements and deletions with regard to reference sequences (A) and the phylogenetic tree derived from 16S rRNA gene variable regions in 10 studied psychrophilic pseudomonade strains (B). The arrow indicates the target for Z-SpecPs probe hybridization. The phylogenetic tree is constructed using UGENE software.

\begin{tabular}{|c|c|c|c|c|c|c|c|c|c|c|c|c|c|c|c|c|}
\hline \multirow{2}{*}{ Strain } & \multicolumn{11}{|c|}{ Growth at low temperatures, ${ }^{\circ} \mathrm{C}$} & \multicolumn{4}{|c|}{ Antagonism } & \multirow[b]{2}{*}{$\mathrm{AU}$} \\
\hline & \begin{tabular}{|l|l|l|}
15 & 12 & 10 \\
\end{tabular} & \begin{tabular}{l|l|l}
0 & 9
\end{tabular} & 8 & 7 & 6 & 5 & 4 & 3 & 2 & 1 & 0 & $P S$ & $C M$ & $F S$ & $A A$ & \\
\hline Pseudomonas sp. RM13C & & & & & & & & & & & & 10 & 12 & 17 & 22 & - \\
\hline Pseudomonas sp. RF13H & & & & & & & & & & & & 12 & 10 & 22 & 27 & + \\
\hline Pseudomonas sp. RF14J & & & & & & & & & & & & 7 & 8 & 13 & 15 & - \\
\hline Pseudomonas sp. AF12F & & & & & & & & & & & & 12 & 10 & 10 & 12 & - \\
\hline Pseudomonas sp. AF24C & & & & & & & & & & & & 5 & 2 & 7 & 8 & - \\
\hline Pseudomonas sp. RM13D & & & & & & & & & & & & 10 & 12 & 15 & 17 & - \\
\hline Pseudomonas sp. RM11C & & & & & & & & & & & & 8 & 12 & 22 & 22 & - \\
\hline Pseudomonas sp. RM14B & & & & & & & & & & & & 14 & 17 & 17 & 12 & + \\
\hline Pseudomonas sp. RF12C & & & & & & & & & & & & 1 & 3 & 4 & 4 & - \\
\hline Pseudomonas sp. RF14H & & & & & & & & & & & & 1 & 2 & 2 & 5 & - \\
\hline
\end{tabular}

B

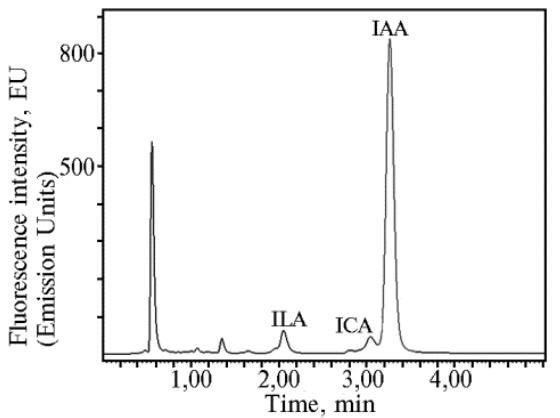

Fig. 2. Physiological and biochemical (potentially adaptive) properties of studied pseudomonade strains: A - psychrophilic growth, diameter $(\mathrm{mm})$ of growth inhibition zones of Pseudomonas solanacearum (PS), Clavibacter michiganensis subsp. sepedonicus (CM), Fusarium solani (FS), Alternaria alternata $(A A)$ and auxin production (AU, presence or absence); $\mathrm{B}$ - results of culture broth analysis for RF13H strain grown on L-tryptophan containing medium, by high performance liquid chromatography method (Waters ACQUITY HPLC H-class with fluorescence detector (Waters, USA): ILA - indolyl-3-lactic acid, ICA - indolyl-3-carboxylic acid, IAA - indolyl-3-acetic acid.

Evaluation of antagonistic activity with regard to phytopathogenic and pu- 
trefactive potato microorganisms (Fig. 2, A) showed the sign to be clearly manifested in some strains (RF13H, RF14J, RM14B, RF12C) (inhibition of pathogens causing potato losses during refrigerated storage). Pseudomonas spp. RF13H strain, selected for a complex of physiological properties, was more prominent in activity against fungi and bacteria, formed optically clear zones without inclusions of test culture mycelium and plant pathogen and produced auxin-like phytohormones (see Fig. 2, B). For this strain considered as prospective for practical use, we have studies physiological activity during colonization of tuber surface.

Pseudomonas sp. RF13H introduced strain count dynamics and impact on storage. Tubers were inoculated with a monoculture of pseudomonade test strain during post-harvesting (treatment) period to create favorable conditions for adaptation of antagonist bacteria and their activity. This period takes 14 days according to the conventional potato storage technique, during which tubers are kept at $18{ }^{\circ} \mathrm{C}$. This mode also ensures active suberization of mechanical damages and reinforcement of tuber surface tissues.

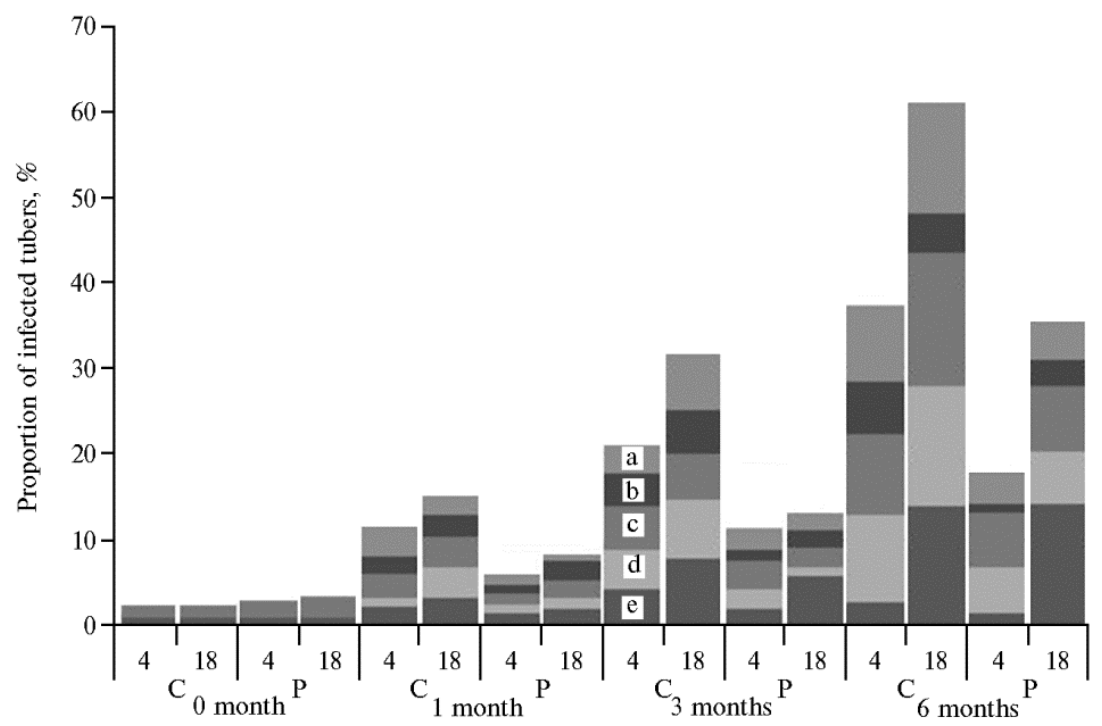

B

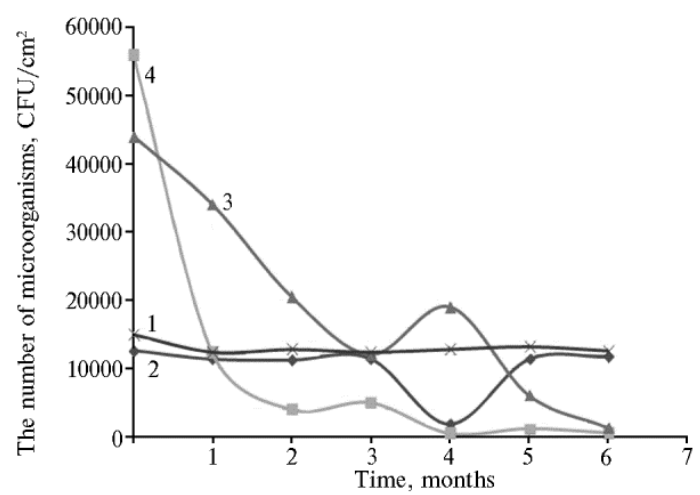

Fig. 3. Phytopathogenic load on tuber surface of potato (Solanum tuberosum L.) Nevskii variety due to the effect of Pseudomonas sp. RF13H introduced strain (A) and its count compared to autochthon microflora depending on temperature $(\mathrm{B})$ during storage: $\mathrm{a}-$ Penicillium spp., b - Rhizoctonia spp., c Fusarium spp., d - Phytophtora spp., e Phoma exiqua; $\mathrm{C}$ and $\mathrm{P}$ - control (untreated tubers) and pseudomonade introduction, respectively; 1 - control, 2 - alien bacteria, 3 and $4-$ Pseudomonas sp. RF13H strain count during storage at $4{ }^{\circ} \mathrm{C}$ and $18{ }^{\circ} \mathrm{C}$ respectively.

Total count of mesophilic saprotrophic microflora per unit of tuber surface varied within $10^{3}-10^{4} \mathrm{CFU} / \mathrm{cm}^{2}$. Pseudomonas sp. RF13H introduction affected the phytopathogenic compositions (Fig. 3, A), as well as proportion and dynamics of saprotrophic microflora counts (see Fig. 3, B) during long-term storage (for 6 months). The studied microorganism survived good enough on tuber sur- 
face and maintained its count during the experiment. It can be noted that refrigerated storage had generally positive effect on RF13H strain due to its physiological properties and characteristics of bacterial population as a whole. It is known that various bacteria species maintain viability on solid growth media at $4{ }^{\circ} \mathrm{C}$ during a long period (up to half a year) [33]. Drying of culture media, causing death of a population, serves as a limiting factor. Possibly, the same happens on tuber surface at normal storage temperature: decrease in introduced strain count was most pronounced in this case, and residual amounts of the strain were observed in 6 months. Pseudomonas sp. RF13H count at $4{ }^{\circ} \mathrm{C}$ was sufficiently stable during 5 months and decreased significantly by the end of the storage, when residual amounts of this strain were observed.

However, effect of the strain on composition and the count of phytopathogenic fungi (see Fig. 3, A) turned out to be significant, according to the phytopathological analysis. It has been found out that development of phytopathogenic micromycetes (Rizoctonia spp., Fusarium spp., Penicillium spp., Phytophthora spp., Phoma exiqua) was the most pronounced during storage. Their frequency in the population decreased in as little as 30 days (to the greatest extent during refrigerated storage). Average proportion of tubers affected by all types of infections after bacterial culture treatment decreased from 11.5 to $5.9 \%$ at refrigerated storage, and from 15.0 to $8.3 \%$ at room temperature in 30 days. This trend was preserved for 3 months, i.e. the proportion of infected tubers amounted to $30 \%$ in control samples, while introduction of bacterial strain ensured reduction of this index up to $10-13 \%$. In 6 months significant tuber infection (up to $60.0 \%$ ) was observed at room temperature, while at refrigerated storage the parameter was about half as great $(37.4 \%)$.

Antioxidant protection (AP) enzymes, which not only control free radical formation, but also perform important signal functions in cells (both in stress and normal conditions), play a special role in cellular activity regulation [34-36]. Oxidation-reduction processes are considered as one of the bases of physiological and biochemical mechanisms determining viability and preservation of potato tubers. Long-term storage or unfavorable conditions leads to lipid peroxidation (LPO) products accumulation, and antioxidant system function decreases [37].

In case of treatment with beneficial bacteria which reinforces this function, resistance to pathogens increases due to increase in plant immunity and formation of a barrier, preventing pathogen infiltration. It is known that microorganisms inhabiting potato surface induce generation of reactive oxygen species (ROS), so beneficial microflora can be used for ensure plant cell defense response to infection. In this context, it was considered important to study the effect of Pseudomonas sp. $\mathrm{RF} 13 \mathrm{H}$ on ROS formation and antioxidant protection enzyme functioning [38].

Activity of pro- and antioxidant system in tubers of potato (Solanum tuberosum L.) Nevskii variety after treatment with Pseudomonas sp. RF13H biocontrol strain, depending of storage temperature

\begin{tabular}{|c|c|c|c|c|c|c|c|c|}
\hline \multirow{2}{*}{$\begin{array}{l}\text { Storage peri- } \\
\text { od, months }\end{array}$} & \multicolumn{4}{|c|}{ Control (water treatment) } & \multicolumn{4}{|c|}{ Test } \\
\hline & LPO & SOD & CAT & $\mathrm{PO}$ & LPO & SOD & CAT & $\mathrm{PO}$ \\
\hline \multicolumn{9}{|c|}{ Storage at $4^{\circ} \mathrm{C}$} \\
\hline 0 & 8.4 & 0.05 & 0.51 & 60.8 & 8.6 & 0.57 & 0.57 & 69.4 \\
\hline 1 & 6.7 & 0.03 & 0.34 & 74.5 & 6.3 & 1.61 & 0.56 & 104.8 \\
\hline 3 & 6.3 & 0.07 & 0.13 & 50.1 & 5.8 & 1.23 & 0.43 & 112.6 \\
\hline 6 & 9.8 & 0.05 & 0.36 & 84.3 & 6.8 & 1.83 & 0.78 & 120.1 \\
\hline \multicolumn{9}{|c|}{ Storage at $18^{\circ} \mathrm{C}$} \\
\hline 0 & 8.7 & 0.05 & 0.54 & 60.2 & 8.5 & 0.74 & 0.56 & 106.4 \\
\hline 1 & 9.4 & 0.04 & 0.38 & 79.3 & 6.9 & 1.83 & 0.66 & 120.5 \\
\hline 3 & 10.1 & 0.06 & 0.25 & 67.2 & 6.2 & 1.98 & 0.71 & 110.3 \\
\hline 6 & 12.3 & 0.08 & 0.41 & 88.9 & 7.3 & 2.11 & 0.84 & 124.7 \\
\hline $\mathrm{LSD}_{05}$ & 0.80 & 0.01 & 0.50 & 5.40 & 2.10 & 0.30 & 0.10 & 7.10 \\
\hline Note. LPO & ipid $p$ & tion, & ; SOL & peroxi & utase & CAT & $\begin{array}{l}\text { talase, } \\
\text { eight }\end{array}$ & $\min \cdot g)$ \\
\hline
\end{tabular}


Long-term storage led to rapid inhibition of SOD and CAT and accumulation of LPO products (Table), including MDA. Peroxydase activity did not change during storage. High temperature contributed to activation of free radical reactions and LPO, leading to decrease in potato viability and quality. Enzyme activity decreased periodically during 3 months in all samples. At that, enzyme activity growth correlated with LPO increase. Both enzyme and LPO activity increased after 6 months of storage due to end of potato physiological rest stage. In case of biocontrol strain treatment significant activation of all studied enzymes was observed, which is indicative of increase in tuber protective potential during long-term storage.

Strategy of potato tuber surface colonization by Pseudomonas sp. RF13H. In order to study survival of introduced RF13H strain at refrigerated potato storage, we have developed oligonucleotide probe Z-SpecPs $\left(5^{\prime} \rightarrow 3^{\prime}\right.$ : CAAACCACTACGCGCGCTTAC), which was binding specifically with the respective unique target during FISH (see Fig. 1, A). In 24 hours after tuber inoculation localization of biocontrol bacteria microorganism visualized using ZSpecPs probe and confocal scanning laser microscopy was characterized by unordered and uneven distribution on outer layer of tuber surface. Several rows of live (phellogen and phelloderm) and dead (phellem) cells were observed in periderm; the cells were extremely closely packed, had rectangular shape with occasional isodiametric (round) and elongated cells. Suberized covering layer protects tubers from moisture loss, plant pathogen infiltration and other adverse external impacts. The majority of cells of RH13H strain did not occupy certain niches on the surface during the first day, and only a small part was localized in top periderm damage areas.

Unevenness of tuber surface was revealed by confocal microscopy. In 2 months of refrigerated storage of treated tubers the microcolonies of biocontrol strain occurred, which were often located in various surface hollows and niches, skin cracks, scratches, cuts, injury and mechanical damage areas (Fig. 5 A, B). Apparently, the substances accumulated due to mechanical damages (indolylacetic, ascorbic and chlorogenic acids, gibberellin, ATP) [39] which stimulate wound reaction (wound periderm formation) attract the introduced bacteria.

Moreover, high density of inoculum was observed at the border between tuber periderm cells (see Fig. 5 A, a), where the bacteria were usually located along narrow elongated longitudinal cells, differentiated in the secondary surface tissue zone. Most likely, small rectangular slightly thickened and closely packed cells with thin membranes are metabolically active phellogen cells. They have thick viscous cytoplasm and numerous organelles related to synthesis processes, ensuring nuclear and cytoplasm division [40]. It can be assumed that biochemical activity in phellogen contributes to biocontrol strain colony formation. At the same time, it has been found that the strain can actively colonize lenticels, the microscopic surface slots (holes), through which air oxygen is supplied to a tuber and carbon dioxide and water vapor are removed (tuber breathing) (see Fig. 5, D).

Fungal mycelium occupying some local areas of infected periderm was observed during tuber surface microscopy. Introduced pseudomonade bacterial cell clusters were detected in close proximity to mycelium (see Fig. 4, A). Early phase of fungal development was observed in the top cell layer, with formation of intracellular (more rarely intercellular) mycelium. Egg- or lemon-shaped zoosporangia similar to Phytophthora infestans zoosporangia had thin smooth membrane and a prominent tubercle on the top, but no rusting color common to late blight was observed on tuber dissection.

It should be noted once again that tuber storage at $18{ }^{\circ} \mathrm{C}$ for 14 days might have played a significant role in effectiveness of introduced strain. It has 

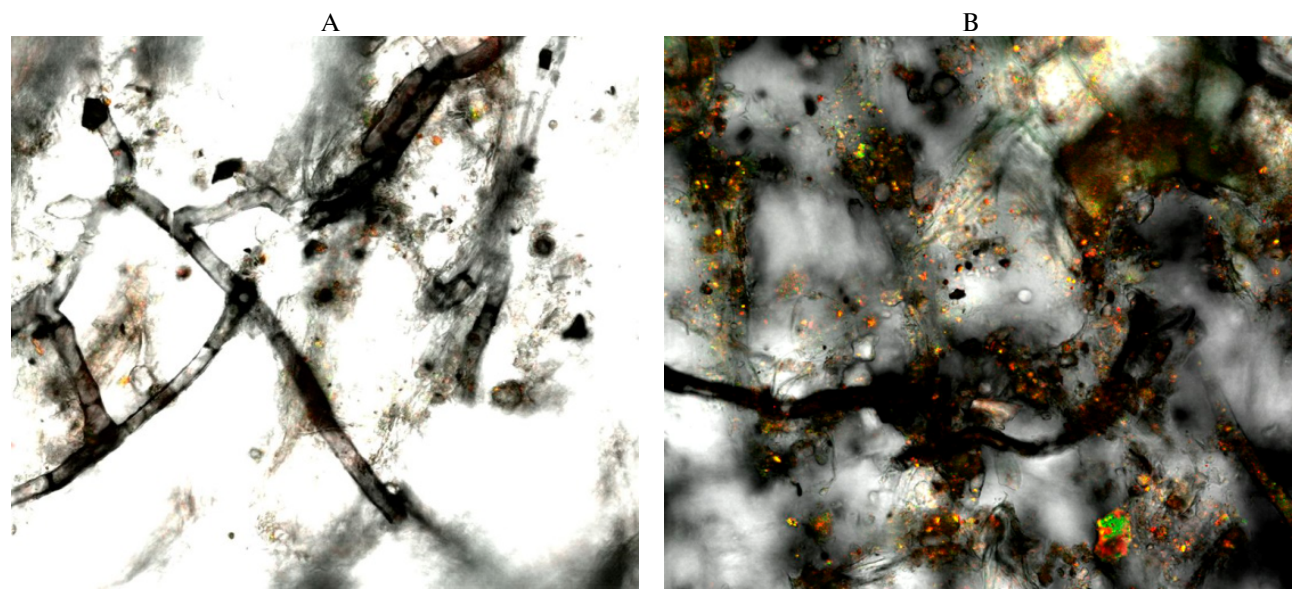

Fig. 4. Localization of introduced Pseudomonas sp. RF13H bacteria on tuber surface of potato Sudarynya variety $24 \mathrm{~h}$ after inoculation: A - fungal mycelium, fluorescence indicates the presence of RF13H strain cell clusters; B - scattered irregularly localized bacterial microcolonies on tuber surface, high bacterial count per area unit. FISH (6FAM fluorochrome, Cy3) with confocal scanning laser microscopy (Leica TCS SPE, Leica Mikrosysteme Vertrieb GmbH, Germany).

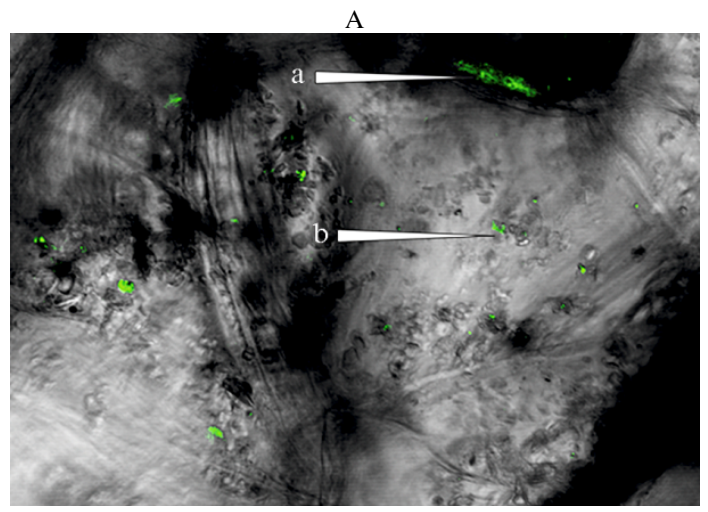

B

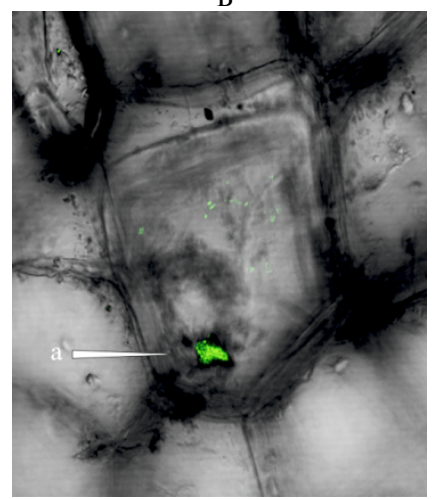

Fig. 5. Localization of introduced Pseudomonas sp. RF13H bacteria on tuber surface of potato Nevskii variety after 2 month storage: A - most common localization, periderm cell junctions (a) and surface of the cells (b); B, C - formation of RF13H biocontrol strain microcolonies in surface microcracks (wounds) and scratches; D - active colonization of lenticel internals. FISH (6FAM fluorochrome) with confocal scanning laser microscopy (Leica TCS SPE, Leica Mikrosysteme Vertrieb GmbH, Germany).

their adaptation to the respective ecological niche. It is important for successful competition with already existing native microflora, and synthesis and accumulation of antifungal metabolites. It is known that mechanisms of adaptation and synthesis of bioactive compounds, as well as chemotactic characteristics of population cells correlate to the time of incubation [41]. A host plant, in its turn, also affects the result of biocontrol: quantitative composition of introduced bacteria depends on physiological condition, variety and type of biological object, and secretion of nutrients by tuber cells stimulates chemotaxis of microorganisms. 
Hollows, microcracks and niches ensure physical separation of bacteria and serve for accumulation and secretion of metabolites, liquids, etc., creating favorable conditions for physiological activity of biocontrol strain.

Visualization of introduced Pseudomonas sp. RF13H strain in vivo on tuber surfaces during storage is indicative of high adaptability of these bacteria at low temperatures, which is important in competition for nutrition sources and localization under conditions of epiphytic microbiome.

Thus, introduced biocontrol bacteria which inhibit pathogen development and reduce losses during storage have a significant potential to ensure environmentally sound products. The ability of Pseudomonas sp. RF13H strains to colonize plants and simultaneously protect them from pathogens, observed by us, makes this strain promising for agricultural technologies.

\section{REFERENCES}

1. Ph a t a k H.C. The role of seed and pollen in the spread of plant pathogens particularly viruses. Tropical Pest Management, 2009, 26(3): 278-285 (doi: 10.1080/09670878009414413).

2. Darrasse A., Arnaud Darsonval A., Boureau T., B risset M.-N., Durand K., J a c q u e s M.-A. Transmission of plant-pathogenic bacteria by nonhost seeds without induction of an associated defense reaction at emergence. Appl. Environ. Microbiol., 2010, 76(20): 6787-6796 (doi: 10.1128/AEM.01098-10).

3. Russian Federation. Available http://www.fao.org/faostat/en/\#country/185. No date.

4. B a le J.S., van Le ntere n J.S., B igle r F. Biological control and sustainable food production. Phil. Trans. R. Soc. B, 2008, 363(1492): 761-776 (doi: 10.1098/rstb.2007.2182).

5. Vuro M. Enhancing biocontrol agents and handling risks. M. Vurro, J. Gressel, T. Butt, G.E. Harman, A. Pilgeram, R.J. Leger, D.L. Nuss (eds.). IOS Press, Amsterdam, 2001.

6. Rosenblueth M., Martínez-Romero E. Bacterial endophytes and their interactions with hosts. Mol. Plant-Microbe Interact., 2006, 19: 827-837 (doi: 10.1094/MPMI-19-0827).

7. Hollid a y P. A dictionary of plant pathology. Cambridge University Press, Cambridge, 1989 (doi: 10.1017/S0014479700001393).

8. Schulz B., B o yle C. What are endophytes? In: Microbial root endophytes. B.J.E. Schulz, C.J.C. Boyle, T.N. Sieber (eds.). Springer-Verlag, Berlin, 2006: 1-13.

9. Maksimov I.V., Abizgil'dina R.R., Pusenkova L.I. Prikladnaya biokhimiya i mikrobiologiya, 2011, 47: 373-385 (doi: 10.1134/S0003683811040090) (in Russ.).

10. Manter D.K., Delgado J.A., Holm D.G., Stong R.A. Pyrosequencing reveals a highly diverse and cultivar-specific bacterial endophyte community in potato roots. Microb. Ecol., 2010, 60: 157-166 (doi: 10.1007/s00248-010-9658-x).

11. İ c e og lu O., Falca o S alles J., va n Els as J.D. Soil and cultivar type shape the bacterial community in the potato rhizosphere. Microb. Ecol., 2012, 63: 460-470 (doi: 10.1007/s00248-011-9930-8).

12. Weinert N., Piceno Y., Ding G.C., Meincke R., Heuer H., Berg G., Schloter M., Andersen G., S m a 11 a K. PhyloChip hybridization uncovered an enormous bacterial diversity in the rhizosphere of different potato cultivars: many common and few cultivar-dependent taxa. FEMS Microbiol. Ecol., 2011, 75: 497-506 (doi: 10.1111/j.1574-6941.2010.01025.x).

13. Andreote F.D., Rocha U.N., Arabjo W.L., Azevedo J.L., van Overbeek L.S. Effect of bacterial inoculation, plant genotype and developmental stage on root-associated and endophytic bacterial communities in potato (Solanum tuberosum). Antonie Van Leeuwenhoek, 2010, 97: 389-399 (doi: 10.1007/s10482-010-9421-9).

14. Reiter B., Pfe ifer U., S chwab H., S essits ch A. Response of endophytic bacterial communities in potato plants to infection with Erwinia carotovora subsp. atroseptica. Appl. Environ. Microbiol., 2002, 68: 2261-2268 (doi: 10.1128/AEM.68.5.2261-2268.2002).

15. G a rbeva P., Overbeek L.S.S., Vuurde J.W., E1s as J.D.D. Analysis of endophytic bacterial communities of potato by plating and denaturing gradient gel electrophoresis (DGGE) of 16S rDNA based PCR fragments. Microb. Ecol., 2001, 41: 369-383 (doi: 10.1007/s002480000096).

16. Pe rombelon M.C.M., Gullings-Handley J., Ke $1 \mathrm{man}$ A. Population dynamics of Erwinia carotovora and pectolytic Clostridium spp. in relation to decay of potatoes. Phytopathology, 1979, 69: 167-173 (doi: 10.1038/srep11606).

17. Koiv V., Roosaare M., Vedler E., Kivistik P.A., Toppi K., Schryer D.W., Re m m M., Te n s o n T., M a A. Microbial population dynamics in response to Pectobacterium atrosepticum infection in potato tubers. Scientific Reports, 2015, Article number 11606: 118 (doi: 10.1038/srep11606).

18. Andreote F.D., de Araújo W.L., de Azevedo J.L., van Elsas J.D., da Rocha U.N., van Overbeek L.S. Endophytic colonization of potato (Solanum tuberosum L.) by a novel com- 
petent bacterial endophyte, Pseudomonas putida strain P9, and its effect on associated bacterial communities. Appl. Environ. Microbiol., 2009, 75: 3396-3406 (doi: 10.1128/AEM.00491-09).

19. Verma V.C., Gange A.C. Advances in endophytic research. Springer Science \& Business Media, Berlin, 2013 (ISBN 978-81-322-1575-2).

20. $\mathrm{S} \mathrm{h} \mathrm{ch}$ e r b a k ov A.V. Endofitnye soobshchestva sfagnovykh mkhov kak istochnik bakterii - effektivnykh assotsiantov sel'skokhozyaistvennykh kul'tur. Avtoreferat kandidatskoi dissertatsii [Endophytic community of sphagnum moss as a source of crop effective bacterial assiociants. PhD Thesis]. St. Petersburg, 2014 (in Russ.).

21. Korostik E.V., P i na e v A.G., Akhte mova G.A., Andronov E.E. Ekologicheskaya genetika, 2006, 4(4): 32-37 (in Russ.).

22. Magnus s o n J., S chnure r, J. Lactobacillus coryniformis subsp. coryniformis strain Si3 produces a broad-spectrum proteinaceous antifungal compound. App. Envir. Microbiol., 2001, 67(1): 1-5 (doi: 10.1128/AEM.67.1.1-5.2001).

23. Z e nova G.M., S te panov A.L., Likhachev A.A., M a n u c harova N.A. Praktikum po biologii pochv [Soil biology practicum]. Moscow, 2002 (in Russ.).

24. Te p per E.Z., Shil'nikova V.K. Praktikum po mikrobiologii [Microbiology practicum]. Moscow, 2004 (in Russ.).

25. S in ' k e vi ch M.S., N a rai k i na N.V., T ru nova T.I. Fiziologiya rastenii, 2011, 58: 875882 (in Russ.).

26. Ku m a r G.N., K now le s N.R. Changes in lipid peroxidation and lipolytic and free-radical scavenging enzyme during aging and sprouting of potato (Solanum tuberosum L.) seed-tubers. Plant Physiol., 1993, 102: 115-124 (doi: 10.1104/pp.102.1.115).

27. Naraikina N.V., S in'kevich M.S., D e min I.N., S e livanov A.A., Mosh k o v I.E., T r u n o v a T.I. Fiziologiya rastenii, 2014, 61: 359-366 (in Russ.).

28. Integrated DNA Technologies. Available https://eu.idtdna.com/calc/analyzer. No date.

29. Cardinale M., Vieira d e Castro J., Muller H., B erg G., Grube M. In situ analysis of the bacterial community associated with the reindeer lichen Cladonia arbuscular reveals predominance of Alphaproteobacteria. FEMS Microbiol. Ecol., 2008, 66: 63-71 (doi: 10.1111/j.1574-6941.2008.00546.x).

30. Shcherbakov A.V., Bragina A.V., Kuz'mina E.Yu., Berg K., Muntyan A.N., Makarova N.M., Mal'fanova N.V., Kardinale M., Berg G., Chebotar' V.K., Tik ho novi c h I.A. Mikrobiologiya, 2013, 82(3): 312-322 (in Russ.).

31. Peix A., Ramíre z-B a he na M.H., Ve lázquez E. Historical evolution and current status of the taxonomy of genus Pseudomonas. Infection, Genetics and Evolution, 2009, 9(6): 1132-1147 (doi: 10.1016/j.meegid.2009.08.001).

32. Cornelis P. Pseudomonas: genomics and molecular biology. Horizon Scientific Press, Pool, 2008 (ISBN 978-1-904455-19-6).

33. Toth E.M., Borsodi A.K, Felfoldi T., Vajna B., Sipos R., Marialigeti K. Practical microbiology. Eötvös Loránd Tudományegyetem, Budapest, 2013.

34. W e ge n e r C.B., J a n s e n G. Antioxidant capacity in cultivated and wild Solanum species: The effect of wound stress. Food Funct., 2010, 1: 209-218 (doi: 10.1039/C0FO00063A).

35. G r a c e S.C. Phenolics as antioxidants. In: Antioxidants and reactive oxygen species in plants. N. Smirnoff (ed.). Blackwall Publishing Ltd, Oxford, 2005.

36. W e g e ne r C.B., J a n s e n G. Antioxidants in different potato genotypes: effect of drought and wounding etress. Agriculture, 2013, 3: 131-146 (doi: 10.3390/agriculture3010131).

37. Verkhoturov V.V., T o p or is h cheva V.K. Khranenie i pererabotka sel'khozsyr'ya, 2003, 9: 26-30 (in Russ.).

38. K i p r u s h i n a E.I. Vestnik Mezhdunarodnoi akademii kholoda, 2007, 3: 34-38 (in Russ.).

39. Kolodyaznay a V.S., K i prushki na E.I. Kholodil'naya tekhnologiya pishchevykh produktov (biokhimicheskie i fiziko-khimicheskie osnovy) [Food refrigeration technolofies: biochemical amd phsysicochemical aspects]. St. Petersburg, 2008 (in Russ.)

40. P a u to v A.A. Morfologiya $i$ anatomiya vegetativnykh organov rastenii [Morphology and anatomy of plant vegetative organs]. St. Petersburg, 2012 (in Russ.).

41. O le s k i n A.V., B o t vi n k o I.V. Mikrobiologiya, 2000, 69: 309-327 (in Russ.). 